\title{
Biochemical Responses of Shoot and Root Tissues of Sainfoin (Onobrychis viciifolia Scop.) to NaCl-Salt Stress Under In Vitro Conditions
}

\author{
Ramazan Beyaz \\ Department of Soil Science and Plant Nutrition, Faculty of Agriculture, Kırşehir Ahi Evran University, 40100 Kırşehir, Turkey \\ E-mail: ramazanbeyaz@gmail.com, ORCID: https://orcid.org/0000-0003-4588-579X
}

\begin{tabular}{l|l}
\hline A R T I C L E I N F O & A B S T R A C T \\
\hline Research Article & $\begin{array}{l}\text { Sainfoin (Fabaceae) is one of the most critical animal forage crops. However, the tolerance of } \\
\text { sainfoin is low against to salinity. This study aims to investigate biochemical responses of the } \\
\text { shoot and root tissue of sainfoin seedlings to moderate salt stress under in vitro conditions. For } \\
\text { this aim, the seed of sainfoin were sown MS medium containing 100 mM NaCl. Antioxidant } \\
\text { enzymes (CAT, SOD, APX, and GR), proline and malondialdehyde (MDA) contents were } \\
\text { measured in shoot and root tissue of 35-day-old seedlings of sainfoin. A significantly higher } \\
\text { constitutive catalase (CAT) and superoxide dismutase (SOD) activity was observed in shoot } \\
\text { tissues when compared to root tissues. Overall, salt stress caused significant more enhancement in } \\
\text { the activity of antioxidant enzymes (CAT, SOD, APX, and GR) in shoot tissues than root tissue. }\end{array}$ \\
$\begin{array}{l}\text { Accepted : }: 29 / 11 / 2018 \\
\text { On the other hand, among the antioxidant enzymes, SOD seems to be more active in both tissues } \\
\text { of sainfoin. Interestingly, the activity of GR reduced in both tissue under salt stress. The content } \\
\text { of proline and MDA has been increased under salt stress and this increase has been more in the } \\
\text { root tissue. This study has revealed biochemical responses to salt stress in different organs of } \\
\text { sainfoinf }\end{array}$ \\
$\begin{array}{l}\text { NaCl } \\
\text { Antioxidant enzymes } \\
\text { Proline content } \\
\text { Malondialdehyde (MDA) content }\end{array}$
\end{tabular}

(9) (1) (8) This work is licensed under Creative Commons Attribution 4.0 International License

\section{Introduction}

In plant production, the one of the most important factor limiting crop productivity is salinity (Piwowarczyk et al. 2014). According to the FAO Land and Plant Nutrition Management Service, over 3\% of the world's land is suffering from salinity, which cover over 397 million hectares. Much of the world's land is not cultivated, but a significant proportion of cultivated land is salt-affected. Of the current 230 million ha of irrigated land, 45 million ha are salt-affected (19.5\%), and of the 1500 million ha under dryland agriculture, 32 million are salt-affected to varying degrees (2.1\%) (Hefny et al. 2013). Salinity problem is increasing and the struggle for salinity is very difficult. One of the easy solutions to solve this problem is that the cultivation of stress-tolerant species that maintaining high productivity (Piwowarczyk et al., 2014).

Morphological, physiological, biochemical and molecular responses of plants to stressors are widely used to determine the stress tolerances. Environmental stress factors, including salt stress, cause the formation of reactive oxygen species (ROTs) known as oxidative stress in plant cells. These reactive oxygen species have many adverse effects on the cell such as membrane peroxidation, protein denaturation, and DNA damage. In order to protect themselves against ROSs, plants have a comprehensive defense mechanism including main antioxidative enzymes such as superoxide dismutase (SOD; EC 1.15.1.1), catalase (CAT; EC 1.11.1.6), ascorbate peroxidase (APX; EC 1.11.1.11), and glutathione reductase (GR; EC 1.8.5.1) and important osmolytes like proline. Lipid peroxidation can be defined as the oxidative deterioration of lipids containing any number of carbon-carbon double bonds. Lipid peroxidation is a well-established mechanism of cellular injury in both plants and animals, and is used as an indicator of oxidative stress in cells and tissues (El-Beltagi and Mohamed, 2013). In the previous studies, all these essential parameters showed as an indicator of tolerances against the various stress factors, involving salt stress in different plants, including Fabaceae (Bandeoğlu et al., 2004; Yasar et al., 2008; Kusvuran, 2015; Khan and Hemalatha, 2016). 
Sainfoin (Fabaceae) is an important animal forage crops. 160 species of it are known around the world. While sainfoins are spread in a very broad geography from the Baltic Sea to the Mediterranean, Asia Minor, and Siberia. They have accumulated and diversified especially in the Anatolia-Iran-Caucasus triangle. In these regions, 32 out of the 53 species in Iran $(60.4 \%), 27$ out of the 52 species in Turkey $(51.9 \%)$ and 21 out of the 39 species in the Caucasus $(53.4 \%)$ are endemic. In the light of these data, it may be seen that Turkey is one of the important centers of development for this genus (Avc1, 2010). Sainfoin has several superior characteristics. It may be grown in arid, gravelly and calcareous soils. It is more resistant to arid conditions in comparison to other feed plants. Despite all these advantages, sainfoin (O. viciifolia Scop.) has low salinity tolerance (Temel et al., 2016), however there are limited studies (Beyaz et al., 2018; Beyaz et al., 2011; Wu et al., 2017; Uzun et al., 2017) related to any tolerance mechanisms of sainfoin against salinity, including biochemical basis. Tissue cultures may be used in determining physiological and biochemical events and changes that emerge under stress conditions (Babaoğlu and Gürel, 2001). The present study aimed to investigate biochemical responses of the shoot and root tissue of sainfoin seedlings that exposed to salt $(\mathrm{NaCl})$ stress under in vitro conditions. The current study contributed basic information that can use in breeding studies of sainfoin to the literature.

\section{Material and Methods}

Seed Surface Sterilization, Germination of Seeds and Growth Conditions of Seedlings

The dehulled sainfoin seeds were kept in a $20 \%$ commercial bleach solution (ACE, containing 5\% sodium hypochlorite) for 20 minutes for surface sterilization and then rinsed 3 times with sterile distilled water. The sterilized seeds were planted into MS (Murashige and Skoog, 1962) nutrient media that contained 3\% sucrose and was solidified by $0.65 \%$ agar supplemented with $100 \mathrm{mM}$ $\mathrm{NaCl}$, again, in sterile Magenta boxes. All the cultures were kept under white fluorescent light $\left(27 \mu \mathrm{mol} \mathrm{m} \mathrm{m}^{-2} \mathrm{~s}^{-1}\right)$ in a photoperiod of 16 hours of light and 8 hours of dark at $24 \pm 1{ }^{\circ} \mathrm{C}$. Biochemical analyses were conducted in shoot and root tissue of 35-day-old seedlings

\section{Biochemical Analysis}

Contents of malondialdehyde (MDA) and proline, activities of antioxidative enzymes (CAT, SOD, GR and APX) were measured on the shoot and root of 35-day-old seedlings.

\section{Measurement Proline and Lipid Peroxidation (MDA} content)

The malondialdehyde (MDA) contents were determined based on the method described by Lutts et al. (1996). In short, $5 \mathrm{ml}$ of trichloroacetic acid (TCA) $(0.1 \%)$ was added to the sample of $200 \mathrm{mg}$ fresh leaves, and then, centrifuged at $12500 \mathrm{rpm}$ for 20 minutes. $3 \mathrm{ml}$ of the supernatant were taken from $5 \mathrm{ml}$ of extracts. $3 \mathrm{ml}$ of $0.1 \%$ thiobarbituric acid in $20 \%$ trichloroacetic acid (w/v) was added onto equal amounts of each of the supernatants. The A-absorbance of the samples was measured spectrophotometrically at 532 and $600 \mathrm{~nm}$ using a spectrophotometer.

The proline assay was based on the method by Bates et al. (1973), which uses 3\% sulfosalicylic acid for grinding fresh plant samples. The ninhydrin reagent was added to the tubes containing the ground samples, which were then placed in a water bath at $100^{\circ} \mathrm{C}$ for 1 hour. After cooling, $4 \mathrm{ml}$ of toluene was added to the samples. The samples were examined at $520 \mathrm{~nm}$.

\section{Antioxidant Enzyme Analyses}

To determine the enzyme changes in plants under drought and salt stress, approximately $0.5 \mathrm{~g}$ of fresh callus samples in liquid nitrogen were ground in porcelain mortars and homogenized with $8 \mathrm{ml}$ of a $50-\mathrm{mM}$ phosphate buffer solution containing $0.1 \mathrm{mM}$ of Na-EDTA ( $\mathrm{pH}$ of 7.6). The homogenized samples were centrifuged at $15,000 \mathrm{~g}$ for 15 minutes, and the resultant precipitates were used in the enzyme analyses. The samples were kept at $+4^{\circ} \mathrm{C}$ until the enzyme analyses were performed. For enzyme measurements, the final volumes were obtained using the buffer solution (Kuşvuran, 2010).

\section{Superoxide Dismutase (SOD) Activity}

The SOD activity was determined using the method proposed by Çakmak and Marschner (1992) and Çakmak et al. (1995) based on the reduction of NBT (nitro blue tetrazolium chloride) by $\mathrm{O}_{2-}$ under the light. All the solutions were added into the reaction medium: firstly, $0.1 \mathrm{mM}$ of Na-EDTA containing a $50 \mathrm{mM}$ (pH: 7.6) phosphate $(\mathrm{P})$ buffer, then, the enzyme extract (25 to $100 \mu \mathrm{l}$ ) followed by $0.5 \mathrm{ml}$ of $50 \mathrm{mM} \mathrm{Na}_{2} \mathrm{CO}_{3}(\mathrm{pH}$ of 10.2), $0.5 \mathrm{ml}$ of $12 \mathrm{mM}$ of L-methionine, $0.5 \mathrm{ml}$ and $75 \mu \mathrm{M}$ of $\mathrm{p}$ nitro blue tetrazolium chloride (NBT) and $10 \mu \mathrm{m}$ of riboflavin were each added into the medium so that the final volume of the medium was $5 \mathrm{ml}$. The samples were kept under light for 15 minutes and measurements were carried out at $560 \mathrm{~nm}$.

\section{Ascorbate Peroxidase (APX) Activity}

The APX activity was measured using the method proposed by Çakmak and Marschner (1992) and Çakmak et al. (1995) based on the oxidation of ascorbate at $290 \mathrm{~nm}$ $\left(\mathrm{E}=2.8 \mathrm{mM} \mathrm{cm}^{-1}\right)$. By following the method, the final volume of the reaction medium was adjusted to $1 \mathrm{ml}$ by adding $0.1 \mathrm{mM}$ of EDTA containing a $50-\mathrm{mM}$ phosphate buffer ( $\mathrm{pH}$ of 7.6), $0.1 \mathrm{ml}$ and $10 \mathrm{mM}$ of EDTA containing $12 \mathrm{mM}$ of $\mathrm{H}_{2} \mathrm{O}_{2}, 0.1 \mathrm{ml}$ and $0.25 \mathrm{mM}$ of L-ascorbic acid and enzyme extract into the medium, and then the ascorbate concentration was measured spectrophotometrically at $290 \mathrm{~nm}$.

\section{Glutathione Reductase (GR) Activity}

The GR activity was measured using the method proposed by Çakmak and Marschner (1992) and Çakmak et al. (1995) based on the oxidation of NADPH at $340 \mathrm{~nm}$ $\left(\mathrm{E}=6.2 \mathrm{mM} \mathrm{cm}^{-1}\right)$. By following the method, the final volume of the reaction medium was adjusted to $1 \mathrm{ml}$ by adding $0.1 \mathrm{mM}$ of EDTA containing a $50-\mathrm{mM}$ phosphor buffer ( $\mathrm{pH}$ of 7.6 ), $0.1 \mathrm{ml}$ and $0.5 \mathrm{mM}$ of oxidized glutathione (GSSG), $0.1 \mathrm{ml}$ and $0.12 \mathrm{mM}$ of NADPH and enzyme extract into the medium, and then the NADPH oxidation level was measured spectrophotometrically at $340 \mathrm{~nm}$. 


\section{Catalase (CAT) Activity}

The CAT activity was measured based on the decomposition rate of $\mathrm{H}_{2} \mathrm{O}_{2}$ at $240 \mathrm{~nm}\left(\mathrm{E}=39.4 \mathrm{mM} \mathrm{cm}^{-1}\right)$ (Çakmak and Marschner, 1992; Çakmak et al., 1995). In this enzyme analysis, the final volume of the reaction medium was adjusted to $1 \mathrm{ml}$ by adding $0.1 \mathrm{mM}$ of EDTA containing a 50-mM phosphate buffer ( $\mathrm{pH}$ of 7.6), $0.1 \mathrm{ml}$ and $100 \mathrm{mM}$ of $\mathrm{H}_{2} \mathrm{O}_{2}$ and enzyme extract into the reaction medium.

\section{Statistical Analysis}

Three replicates were prepared with 25 seedlings per replication. Data were statistically analysed by Independent-Samples t-test in the "IBM SPSS 22" program (Snedecor and Cochran, 1967).

\section{Results and Discussion}

In this study, changes in antioxidant enzymes (SOD, CAT, APX, and GR), malondialdehyde (MDA) and proline contents were measured in shoot and root of 35day-old seedling under salt stress $(100 \mathrm{mM} \mathrm{NaCl})$.

\section{Responses of Enzymatic Antioxidants}

The responses of antioxidant enzymes to salt stress were different in both tissues (Table 1.). CAT and SOD activities were significantly $(\mathrm{P}<0.01)$ increased $(6.01$ and 2.53 folds, respectively) by $100 \mathrm{mM} \mathrm{NaCl}$ treatments when compared to control in shoot tissue of 35-day-old seedlings. Interestingly, activities of GR was significantly $(\mathrm{P}<0.05)$ reduced (1.03 fold) when compared to control. On the other hand, an increase in APX activity was observed but statistically not significant (Table 1). APX and SOD were significantly $(\mathrm{P}<0.05)$ increased $(1.52$ and 1.75 fold, respectively) in root tissue under stress (Table 2 ). On the other hand, although the activitiy of CAT was increased (1.04 fold), this is not found statistically significant. GR activity was decreased (1.07 fold) in root tissue as the same in shoot tissue under stress (Table 2).

The enzyme SOD is considered the first-line of defense because it catalyzes the first reaction in the ROS detoxification process (Jun and Zhulong, 2015). Therefore, SOD activity upon salt stress exposure provides valuable information about the biochemical mechanism of shoot and root tissues of sainfoin. Overall, the results of this study show that SOD has the constitutive activity among the others in both tissues. On the other hand, the findings indicated that the activity of SOD much higher in shoot tissues (almost 1.5 fold). According to this results, it can be speculated that shoot tissue less effected from salt stress due to higher activity of SOD. Bandeoğlu et al. (2004) indicated root tissues of lentil are protected better than leaves from $\mathrm{NaCl}$ stress-induced oxidative damage due to enhanced total SOD activity under salinity stress (200 $\mathrm{mM}$ ). On the other hand, Kim et al. (2005) reported that the activities of SOD was increased significantly in the root of barley under salt stress $(200 \mathrm{mM})$.

Catalases are one of the major enzymatic antioxidants after SOD, which have the potential to directly dismutase $\mathrm{H}_{2} \mathrm{O}_{2}$ into $\mathrm{H}_{2} \mathrm{O}$ and $\mathrm{O}_{2}$ (Demidchik, 2015) in antioxidant scavenging systems. In the present study, the findings show that CAT activity much higher (almost 6 fold) in shoots than in the roots of sainfoin under stress conditions. It is clear that sainfoin can activate markedly CAT, which might indicate that shoot tissue more sensitive against to stress, to eliminate $\mathrm{H}_{2} \mathrm{O}_{2}$ and restrict the accumulation of ROS in shoot tissue. Bandeoğlu et al. (2004) reported that CAT activity was increased both roots and leaves the tissue in lentil under salt stress, but its higher in roots than leaves. Azevedo Neto et al. (2006) indicated that CAT enzymes had the greatest $\mathrm{H}_{2} \mathrm{O}_{2}$ scavenger activity in both leaves and roots in maize.

The $\mathrm{H}_{2} \mathrm{O}_{2}$ generated by SOD is reduced to water by ascorbate (AsA) catalysed with APX (Asada, 2006). APX is also one of the essential antioxidant enzymes in defence systems. The findings of the present study show that the increase in APX activity was greater in shoot tissue than root tissue (1.03 fold) under salt stress in sainfoin (Table 1. and Table 2.). Similarly, Heidari (2010) indicated that APX activity much higher than root tissue in shoot tissue of canola genotypes. In contrary, Bendeoğlu et al. (2004) reported that the constitutive activity of APX was much higher in roots (almost two-fold) than leaves in lentil. It seems to APX play an important role in to scavenge of ROTs in any tissue of any plants and activity can be changed (increase/decrease) in different tissue of different plants under stress conditions. However, APX seem to have a positive contribution to antioxidant systems in both tissues of sainfoin.

Tables 1 The effect of $100 \mathrm{mM} \mathrm{NaCl}$ stress on biochemical parameters of shoot tissue of 35-day-old seedlings of sainfoin under in vitro conditions

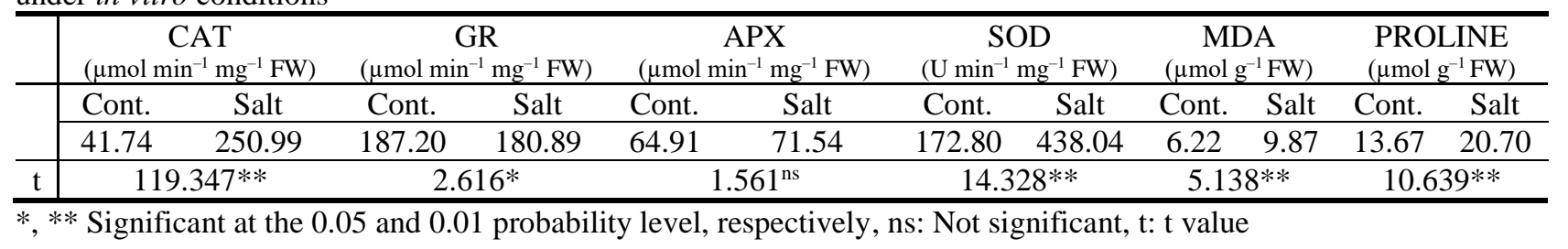

Tables 2 The effect of $100 \mathrm{mM} \mathrm{NaCl}$ stress on biochemical parameters of root tissue of 35-day-old seedlings of sainfoin under in vitro conditions

\begin{tabular}{|c|c|c|c|c|c|c|c|c|c|c|c|}
\hline & 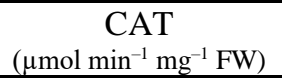 & \multicolumn{2}{|c|}{ 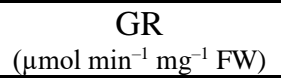 } & \multicolumn{2}{|c|}{ 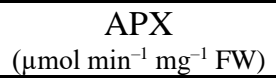 } & \multicolumn{2}{|c|}{ 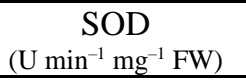 } & \multicolumn{2}{|c|}{$\begin{array}{c}\text { MDA } \\
\left(\mu \mathrm{mol} \mathrm{g}{ }^{-1} \mathrm{FW}\right)\end{array}$} & \multicolumn{2}{|c|}{$\begin{array}{l}\text { PROLINE } \\
\left(\mu \mathrm{mol} \mathrm{g}{ }^{-1} \mathrm{FW}\right)\end{array}$} \\
\hline & $\begin{array}{lc}\text { Cont. } & \text { Salt } \\
86.63 & 90.69 \\
\end{array}$ & $\begin{array}{l}\text { Cont. } \\
180.80\end{array}$ & $\begin{array}{c}\text { Salt } \\
168.53\end{array}$ & $\begin{array}{l}\text { Cont. } \\
45.18 \\
\end{array}$ & $\begin{array}{c}\text { Salt } \\
69.07 \\
\end{array}$ & $\begin{array}{c}\text { Cont. } \\
196.27 \\
\end{array}$ & $\begin{array}{c}\text { Salt } \\
344.18 \\
\end{array}$ & $\begin{array}{c}\text { Cont. } \\
3.26 \\
\end{array}$ & $\begin{array}{c}\text { Salt } \\
11.74 \\
\end{array}$ & $\begin{array}{c}\text { Cont. } \\
6.36 \\
\end{array}$ & $\begin{array}{c}\text { Salt } \\
24.74 \\
\end{array}$ \\
\hline $\mathrm{t}$ & $0.725^{\mathrm{ns}}$ & \multicolumn{2}{|c|}{$1.623^{\mathrm{ns}}$} & \multicolumn{2}{|c|}{$8.209 * *$} & \multicolumn{2}{|c|}{$32.888^{* * *}$} & \multicolumn{2}{|c|}{ 7.581** } & \multicolumn{2}{|c|}{$15.255^{* *}$} \\
\hline
\end{tabular}


The last enzyme of ascorbate-glutathione cycle, GR, catalyses the NADPH-dependent reduction of oxidized glutathione (Bandeoğlu et al., 2004). In the present study, GR activity decreased in both tissue under salt stress and this decreasing is significant at $\mathrm{P}<0.05$ level in shoot tissue of sainfoin (Table 1 and Table 2). Parallel to findings, Bandeoğlu et al. (2004) reported that salt stress caused a decrease in GR activity in roots of lentil. In addition, Abdelgawad et al. (2016) reported that GR activity did not increase in root tissue of maize seedlings up to $150 \mathrm{mM}$ $\mathrm{NaCl}$. In antioxidant enzymes, GR does not play an essential role in scavenging of ROTs in both tissues of sainfoin. On the other hand the decreasing in the activity of GR might be the reasons of a reduction in the supply of reductants such as ATP and NADPH (Ren et al. 2016), the inhibition of enzymes by ROS (Ren et al. 2016) or highest activity of APX which is another essential enzyme in Ascorbate-glutathione (AsA-GSH) cycle such as GR.

Changes in Lipid Peroxidation (Malondialdehyde) and Proline Contents

Lipid peroxidation measured as MDA (malondialdehyde, a product of lipid peroxidation) content considered to be indicators of salt-dependent oxidative damage (Yasar et al., 2008). Compared to shoot tissues a significantly higher malondialdehyde (MDA) contents (1.18 fold) was observed in root tissues of sainfoin (Table 1 and Table 2). This may be due to lesser efforts antioxidant enzymes (except, CAT) to scavenge ROTs in root tissue (Table 1 and Table 2). Similarly, Azevedo Neto et al (2006) reported that the contents of MDA is less in salt- tolerant genotypes of maize than sensitive ones, depend on antioxidant enzymes working capacity. Bandeoğlu et al. (2004) indicated that MDA contents are more in leaf tissue of lentil than root tissue due to less active antioxidant enzymes (SOD, APX, and GR). Azevedo Neto et al. (2006) suggested the reduction of MDA content the in salt tolerant genotype of maize was due to increased antioxidative enzyme activities. Similar results, reported by Shalata et al. (2001) for roots of Lycopersicon pennellii.

Proline is one of the most important osmoprotectant in plants (Bandeoğlu et al., 2004). The findings of the present study show that proline contents were significantly $(\mathrm{P}<0.01)$ increased (1.51 and 3.88 folds, respectively) in both tissue of sainfoin under stress (Table 1 and Table 2). At $100 \mathrm{mM} \mathrm{NaCl}$ stress the increase in roots was much higher $(288 \%)$ than in shoot tissues $(51.42 \%)$. The results of this study were agreement with the findings of Bandeoğlu et al. (2004) in lentil and Heidari (2010) in canola genotypes. In contrary, Meloni et al. (2004) reported that proline content was not significantly increased in both leaves and roots tissue in one of the most important salt-tolerant legumes Prosopis alba (algarrobo) under salt stress (300 and $\left.600 \mathrm{mmol} . \mathrm{L}^{-1}\right)$. The results of more accumulation proline in root contents in root tissue of sainfoin, it may be due to the contact of the root tissue with the direct stress factor. On the other hand, similarly to its generally accepted role in many other species, it is obvious that proline play an important role in antioxidative mechanism of sainfoin.

\section{Conclusion}

On the basis of the data collected here, the biochemical parameters were regularly increased (except, GR) in the shoot and root of sainfoin under stress. Overall, antioxidant enzymes (CAT, GR, SOD and APX) more active in shoot tissue of sainfoin. On the other hand, accumulation of MDA and proline in root tissue much greater than shoot tissue. Among the antioxidant enzymes, SOD seems to be more active in both tissues. However, interestingly the activity of GR decreased in both tissue under stress conditions. Based on present finding, it is concluded that, under salt stress shoot tissues of sainfoin underwent greater oxidative stress-mediated damage when compared with root tissues. The reason for the higher extent of protection from oxidative damage in shoot tissues seems to be due to higher SOD activity and a significant enhancement of CAT activity under salt stress conditions. The results of the present study may provide a comparative information between shoot and root tissue of sainfoin to elucidate the biochemical mechanism for antioxidant defense systems under salt stress. On the other hand, to understand the mechanism of antioxidant defense systems of sainfoin plants, there is need more biochemical, physiological and molecular works.

\section{References}

AbdElgawad H, Zinta G, Hegab MM, Pandey R, Asard H, Abuelsoud W. 2016. High Salinity Induces Different Oxidative Stress and Antioxidant Responses in Maize Seedlings Organs. Frontiers in Plant Science 7(216); 1-11.

Asada K. 2006. Production and Scavenging of Reactive Oxygen Species in Chloroplasts and Their Functions. Plant Physiology141: 391-396.

Avc1 S. 2010. Collection of Wild Sainfoin (Onobrychis Sp.) Species of Turkey And Determination of Their Morphological Characteristics, Ph.D. Thesis, Ankara University.

Azevedo Neto AD, Prisco JT, En'eas-Filho J, Abreu CEB, Gomes-Filho E. 2006. Effect of salt stress on antioxidative enzymes and lipid peroxidation in leaves and roots of salttolerant and salt-sensitive maize genotypes. Environmental and Experimental Botany 56(2006) :87-94.

Babaoğlu M, Gürel E. 2001. Bitki Biyoteknolojisi- 2 Genetik Mühendisliği ve Uygulamaları (In Turkish press). University of Selçuk Publication.

Bandeoğlu E, Eyidoğan F, Yucel M, Oktem HA. 2004 Antioxidant responses of shoots and roots of lentil to $\mathrm{NaCl}-$ salinity stress Plant Growth Regulation 42: 69-77.

Bates LS, Waldren RP, Teare ID. 1973. Rapid determination of free proline for water stress studies. Plant Soil 39: 205-207.

Beyaz R, Kaya G, Cocu S, Sancak C. 2011. Response of seeds and pollen of Onobrychis viciifolia and Onobrychis oxyodonta var. armena to $\mathrm{NaCl}$ stress. Sci. Agric. 6(4):477481.

Beyaz R, Sancak C, Yildiz M. 2018. Morphological and biochemical responses of sainfoin (Onobrychis viciifolia Scop.) ecotypes to salinity. Legume Research 41(2): 253-258.

Çakmak I, Atlı M, Kaya R, Evliya H, Marschner H. 1995. Association of High Light and Zinc Deficiency in ColdInduced Leaf Chlorosis in Grapefruit and Mandarin Trees. J. Plant Physiol. 146: 355-360.

Cakmak I, Marschner H. 1992. Magnesium Deficiency and Highlight İntensity Enhance Activities of Superoxide Dismutase, Ascorbate Peroxidase and Glutathione Reductase in Bean Leaves. Plant Physiol. 98:1222-1226. 
Demidchik V. 2015. Mechanisms of Oxidative Stress in Plants: from Classical Chemistry to Cell Biology. Environ. Exp. Bot.109: 212-228.

El-Beltagi HS, Mohamed H. 2013. Reactive Oxygen Species, Lipid Peroxidation and Antioxidative Defense Mechanism. Not Bot Horti Agrobo 41(1):44-57.

Hefny MM, Mohamed E, Metwali R, Mohamed AI. 2013. Assessment of genetic diversity of sorghum (Sorghum bicolor L. Moench) genotypes under saline irrigation water based on some selection indices. Australian J Crop Sci (AJCS) 7(12):1935-1945

Heidari M. 2010. Nucleic Acid Metabolism, Proline Concentration and Antioxidants Enzyme Activity in Canola (Brassica nupus L.) Under Salinity Stress. Agricultural Sciences in China 9(4): 504-511.

Jun You, Zhulong C. 2015. ROS Regulation During Abiotic Stress Responses in Crop Plants. Frontiers in Plant Science. 6:1-15.

Khan MS, Hemalatha S. 2016. Biochemical and molecular changes induced by salinity stress in Oryza sativa L. Acta Physiol Plant. 38:167.

Kim SY, Lim JH, Park MR, Kim YJ, Park TI, Seo YW, Choi KG, Yun SJ. 2005. Enhanced antioxidant enzymes are associatedwith reduced hydrogen peroxide in barley roots under saline stress. Journal of Biochemistry and Molecular Biology 38:218-224.

Kuşvuran Ş. 2010. Relationships Between Physiological Mechanisms of Tolerances to Drought and Salinity in Melons. Department of Horticulture Institute of Natural and Applied Sciences University of Çukurova. (PhD thesis; in Turkish).

Kusvuran A. 2015. The effects of salt stress on the germination and antioxidative enzyme activity of Hungarian vetch (Vicia pannonica Crantz.) varieties. Legume Research 38(1): 2015:51-59

Lutts S, Kinet JM, Bouharmont J. 1996. NaCl-Induced Senescence in Leaves of Rice (Oryza sativa L.) Cultivars Differing in Salinity Resistance. Ann. Bot. 78: 389-398.
Meloni DA, Gulotta MR, Martínez CA, Oliva MA. 2004. The effects of salt stress on growth, nitrate reduction and proline and glycinebetaine accumulation in Prosopis alba. Braz. J. Plant Physiol.16(1):39-46.

Murashige T, Skoog F. 1962. A revised medium for rapid growth and bioassays with tobacco tissue cultures. Physiologia Plantarum 15: 473-497.

Piwowarczyk B, Kamińska I, Rybiński W. 2014. Influence of PEG Generated Osmotic Stress on Shoot Regeneration and Some Biochemical Parameters in Lathyrus Culture. Czech Journal of Genetics Plant and Plant Breeding 50 (2): 77-83.

Ren J, Sun LN, Zhang QY, Song XS 2016. Drought Tolerance Is Correlated with the Activity of Antioxidant Enzymes in Cerasus humilis Seedlings. BioMed Research International 2016:1-9.

Shalata A, Mittova V, Volokita M, Guy M, Tal M. 2001. Response of the cultivated tomato and its wild salt-tolerant relative Lycopersicon pennellii to salt-dependent oxidative stress: the root antioxidative system. Physiol. Plant 112:487494.

Snedecor GW, Cochran WG. 1967. Statistical Methods. The Iowa State University Press, Iowa, USA

Temel S, Keskin B, Şimşek U, Yilmaz İB. 2016. The Effect of Saline and Non-Saline Soil Conditions on Yield and Nutritional Characteristics of Some Perennial Legumes Forages. Journal of Agricultural Sciences 22 (2016): 528538.

Uzun S, Avci S, Ozcan S, Sancak C. 2017. Effects of $\mathrm{NaCl}$ on Germination and Seedling Characteristics of Different Onobrychis Taxa. Fresenius Environmental Bulletin 26(11): 6317-6323.

Wu Gq, Liu HL, Feng RJ, Wang CM, Du YY. 2017. Silicon ameliorates the adverse effects of salt stress on sainfoin (Onobrychis viciaefolia) seedlings. Plant Soil Environ. 63(12): 545-551.

Yasar F, Ellialtioglu S, Yildiz K. 2008. Effect of Salt Stress on Antioxidant Defense Systems, Lipid Peroxidation, and Chlorophyll Content in Green Bean. Russian Journal of Plant Physiology 55(6):782-786. 